\title{
RMIT
}

\author{
Janice Simpson
}

\section{Our Father, Who Art in Heaven: reflecting on how Christian text can influence nonfiction writing}

\begin{abstract}
:
Child adoption practices in twentieth century Australia were largely reliant on Christian agencies to facilitate the separation of child from mother and the subsequent re-homing of that child with others, almost always married couples referred as suitable parents by their local minister or priest. Stories told by adoptees are frequently stories of loss, grief and abandonment, as recorded in memoir, government inquiries and research studies. The creative work presented in this paper is titled another Exodus: men women leaving children. In this work I chose to 'embody' the 'shell' of the King James Version of the first two chapters in Exodus, a book in the Bible's Old Testament. The work forms part of my broader study of experimental writing, in this case combining a bricolage approach to research with the hermit crab form of the lyric essay, undertaken during my creative practices research. The reader is invited to form fresh, and perhaps transformed, understandings of the impact of the Christian churches' role in adoption policy and practice in Australia, and the subsequent effects of that influence and intervention on our collective cultural and emotional psyche.
\end{abstract}

\section{Biographical Note:}

Janice Simpson is a part-time $\mathrm{PhD}$ candidate in the School of Media and Communication at RMIT. Her creative practice research is focused on adoptees' connections to (dis)place. She is exploring the lyric essay and where that might lead in her creation of stories about place, memory and identity. She is working on representing the layers of meaning that make up a person's story, trying to shape these layers as both physical and narrative representations. She has published a travel memoir, Let Sleeping Dogs Lie (2012), and two crime novels Murder in Mt Martha (2016) and A Body of Work (2018).

Keywords:

creative writing - bricolage - hermit crab essay - infant adoption - The Bible 
Forgive, O Lord, my little jokes on Thee

And I'll forgive Thy great big one on me.

- Robert Frost, 1962

\section{Introduction}

Moses in the Bulrushes was read to me in the cold sacristy of Apsley's Church of England - a modest white weatherboard set in a grassed yard on the main street during Sunday School, while my parents were in the church proper, discharging their obligations to faith. There were bulrushes on our farm so I could readily imagine a basket, similar to the picnic basket that accompanied our outings - jammed with two thermoses, a jar of milk, sausage rolls and apple slice - wedged into strappy foliage, tea-tinted water gently lapping a child to sleep. In the illustration accompanying the story, the key image was that of a cherub-faced child. I felt at some deep level a connection with the floating Moses who was obviously comfortable in the illustration I stared at. But, he was also undeniably adrift. This was before I knew I was an adopted child, removed from my mother and father and given to another set of parents, as if they were mine and I was theirs.

\section{A brief history of infant adoption}

Adoption practices from the 1920s until the mid 1980s resulted in suffering for both mothers and children, as documented in numerous government inquiries and research projects (Cole 2013; Gair 2012; Kenny et al. 2012; New South Wales Parliament 1999; Quartly, Swain \& Cuthbert 2013; Quirk 2012; Standing Committee on Social Issues 2000; Swain \& Howe 1996). It is estimated that more than 300,000 babies were adopted in Australia over this sixty-year period (Cole 2013). The Churches and Governments of the day were bipartisan in their support of adoption, which was seen as a simple way to rid society of unwanted children, and at the same time solve the problem of couples that desired children of their own but had no joy in making them.

Until the 1920s, informal fostering or adoption was commonplace and proved an adequate solution for a chronic problem. The foster or adopting parents had access to information about their baby's mother, and vice versa, and in many cases met each other in the 'lying-in' period: 'It was legal and also quite common, for people involved in an adoption to share information about each other' (Department of Families and Community 2009: 197).

In the late 1920s, a campaign began to legalise adoption because of the expressed concerns about how best to protect the interests of adoptive parents. The interests of birth mothers and adopted children were also considered, or so it was claimed at the time (Higgins 2012). Formal adoption legislation designed to introduce secrecy, called 'closed adoption', was passed in Victoria in 1928, following South Australia's lead in 1926 (Higgins 2012). Secrecy was enshrined as a response to the stigma attached to illegitimacy. For many agencies working in the adoption field, it became paramount to achieve a good physical match between child and parents, so that the child could substitute for a biological child, thereby keeping children ignorant of their identity. 
Laws changed again in the 1960s to further restrict information. Birth certificates, reissued as 'extracts', only included the name and details of the adopting parents, again reinforcing that the adopted baby was the biological product of the marriage. Many adoptees say they knew they were different to other children, and report feelings of unease and distance, but were unable to pin their disquiet to any particular event. Often they were told that it was a normal childhood fantasy to imagine parents had adopted them, or that adopted people looked different, and as they did not look different, they therefore could not possibly be adopted (Quartly, Swain \& Cuthbert 2013). This was the point in time, I argue, when silence transformed itself into untruth.

\section{Australian Christians' role in policy and practice regarding removing children from their parents}

The church is and has been a dominant player in Australian public life, influencing the many policies that have shamed and kept secret the identities and true stories of countless people's lives in this nation. Christine Cole argues that 'the process of regulating and reforming single mothers and their children was a national policy to be undertaken by the cooperation of the state and church' (2013: 192) in order to stem what Charles Mackellar, a reformist eugenicist, described as 'national decadence, physical and moral'(Mackellar 1913: 96, Cole 2013: 192). This approach prevailed for six decades, until the mid 1980s. In 1999-2000, the New South Wales Parliament's inquiry into adoption practices subsequently found that 'the attitudes of the churches...that a child out of wedlock was sinful and immoral also had a significant influence on policy and practice' (Standing Committee on Social Issues 2000: 271), issuing Recommendation 17 that 'churches involved in past adoption practices should be encouraged to issue a formal apology' (2000: 186).

The 300,000 children and their mothers who were the subject of forced adoption (Cole 2013; Gillard 2013; Higgins 2012; Kenny et al. 2012; New South Wales Parliament 1999; Quartly, Swain \& Cuthbert 2013) have also been recognised through formal apologies issued by the church and the state. The Catholic Church (Wakatama 2011), the Uniting Church (Rosenbaum 2012), the Salvation Army (2012), and the Anglican Diocese of Queensland (ABC 2012) have all issued apologies for the role they played in forced adoption. These apologies have acknowledged the hurt, pain and distress their practices caused to those involved named as mothers, fathers, children and families.

Worth noting are two other major policy sets affecting children, where the church and the state have issued apologies for their past policies and practices: the Stolen Generations (Human Rights and Equal Opportunity Commission 1997; Read 1981; Rudd 2008) and the Forgotten Children (Rudd 2009; Senate Community Affairs References Committee 2004).

Perhaps the churches were guided by several biblical verses seen as supporting the adoption of children and decrying the birth of illegitimate children: Matthew 18.5: 'Whoever receives one such child in my name receives me'; Psalm 27.10: 'For my father and my mother have forsaken me, but the Lord will take me in'; Deuteronomy 23.2: 'A bastard shall not enter into the congregation of the Lord; even to his tenth generation shall he not enter into the congregation of the Lord'; and the story of Moses as told in Exodus. However the Bible is interpreted, there is no denying that it has been and continues to be a powerful influence on the state. 


\section{The book of books}

For generations, writers have used the Bible to tell stories, craft moral tales, and as a model for characters' salvations and downfalls and everything in between. Referring to the works of Nathaniel Hawthorne, Herman Melville, John Steinbeck and others, Carlos Baker wrote, 'Under the bland surface of a veritable ocean of literary endeavour this whale of Biblical influence conceals its mighty dimensions' (1960: 53), or as Marilynne Robinson writes, 'The Bible is the model for and subject of more art and thought than those of us who live within its influence, consciously or unconsciously, will ever know' (2011). Geoffrey Chaucer, Edmund Spenser and John Bunyan; the Chester, Magi and Innocents plays as well as many of William Shakespeare's works; the poetry of John Milton and William Blake, who called the old and new testaments 'The Great Code of Art' (Frye 1982: xvi); and the fictions written by Charles Dickens and C.S.Lewis all address ethical, moral and political questions that have their roots in biblical references. Norbert Frye argues that the Bible is 'a work of bricolage' (1982: xxi) which sits in the middle of our cultural heritage, regardless of what we think and believe. For me there is an obvious intertextuality between the Old Testament story of Moses and the story of infant adoption in twentieth century Australia, overlaid as the story of Moses is with social, political and moral tales enshrined in public policy.

\section{A note on bricolage and hermit crabs}

First named by Claude Levi-Strauss, the term 'bricolage' has been used variously in the arts (and other fields) to describe what ensues when a diverse array of objects (or ideas) are put together to make something new (1966). Two decades later, Michel de Certeau added to Levi-Strauss by arguing that ordinary people are natural bricoleurs, re-using, re-assembling and re-organising the spaces and messages derived from cultural tradition, language and symbolism for their own purposes (1984). Joe Kincheloe turned to research methodology, arguing that bricolage is a way in which a question is asked or explored, thereby leading to the discovery of new knowledge about the self (2016). He asserts that bricolage, by cultivating researcher creativity, results in an interdisciplinary research approach that addresses 'the complexities of the social, cultural, psychological, and educational domains. Sensitive to complexity, bricoleurs use multiple methods to uncover new insights, expand and modify old principles, and reexamine accepted interpretations in unanticipated contexts' (2016: 687)

The hermit crab essay, proposed by Miller and Paola as a form of lyric essay where the writer uses an existing form to protect its content's 'soft, vulnerable body' (2012: 115), is pertinent. Margot Singer claims that when a writer experiments with the conventions of form, interesting things happen, and the hermit crab style of essay serves as 'an ironic commentary on the material of which it's made' (Walker \& Singer 2013: 79).

The creative work that forms part of this paper focuses on how the church and the state colluded to deprive children of their mothers and mothers of their children. This is one small segment in the vast adoption story, describing changes from the more laissez-faire adoption policies of the late 1920s to those legislated in the 1960s that enshrined secrecy. Individual adoptees' stories are undeniably soft and vulnerable at their centres. By choosing to tell a collective story that focuses on contemporaneous social, political and moral contexts, I hope that readers will form altered 
interpretations and understandings of adoptees' experiences. Closed adoption in Australia is a large story that remains largely untold.

\section{The creative work: another Exodus: men women leaving children}

1. After the time of the Great War, these were the names of the children who came to the shores of their homeland.

2. Hector, Reg, Arthur and Cecil,

3. George, Harold and Frederick,

4. Douglas, and Victor, Leslie and Bert.

5. 'And behold,' spake no man, except in a whisper, 'every soul has eyes that have seen things no man should ever see.'

6. But, in all truth, their God had smote their enemy, and their God did leave him bloodied and torn, in fields stretching widely from warm seas and cold seas, on through rocky mountain passes where olives grew, to the lands where oceans swelled and birds called a warning.

7. Welcomed with rejoicing, arms and hearts opened to these men who had seen things no human should ever see. Government benefactors set upon all those who returned with limbs and lungs intact, and exalted them to begin again, close their eyes to the shadows, make supplication to their God.

8. Yea, there was great rejoicing as the land of the king was made free for their beckoning. To the river flats and plains they went, there to build homes from trees sticky with resin and sap, unlike the olive of the deserts. 'Behold,' sayeth the king, 'raise up cattle and grain from the soil and spread your seeds across the land, therefore to benefit all manner of men.'

9. The king set forth his taskmasters to preach anew. From the cities came trains, swelled with steam and hot from fire, pulling carriages heavy with taskmasters, all manner of domestic animals, seeds and victuals. And so the peoples were told how to turn the mineral-leached ancient soils, still salty with Gondwana waters, into pasture drowsy with grain, hiding there within its folds the withers and flanks of livestock.

10. And the men worked in the name of their God and turned that land into grain and meat, and the children of the land were fruitful, and increased abundantly, and multiplied, and waxed exceeding mighty; and the land was filled with them.

11. The benefactors and their minions quickened their step and sayeth unto the men, 'Whenever it so happens that your eyes might dance with shadows, you must close them tight, for burdens to make the land great are greater than shadows.'

12. But then a mighty sword fell on the king's land, and the king who had forewarning, called together his men. 'Like sand in an hourglass, our funds are run through. Our foundations have crumbled like clay with no straw to bind it. Our countrymen must find nourishment elsewhere.'

13. Which is how it came to pass that men abandoned their women, their children, their animals, their grains, to roam the land where they did but knock on others' doors and in exchange for sugar and tea did but chop wood and dig garden beds.

14. And verily did they see the dark eyes of the home girls peering through fingerheld curtaining, or scattering scraps to hens weak with no grain, or coaxing cows into stalls where their light-girl fingers squeezed milky water from shriveled teats. 
15. Now these were the names of the children.

16. Martha, Molly, Mable and Madge,

17. Nellie, Jessie and Minnie,

18. Alma and Agnes, Audrey and Agatha, who hid away behind pinafores and laboured in kitchens until their time had come. And the fruits of their labours were scattered amid their mothers' mothers' houses and their fathers' fathers' houses. And some were given to strangers there to raise up as their own, far from the houses of their fathers and their mothers.

19. And then one more time arose a foe in the old lands and the king called the men away, berthed them on vessels with horses and rations and arms and munitions, and sailed them off to distant lands from whence their forefathers had come.

20. When that foe was vanquished, the king's men were restored to their homes.

21. Their names were Jack and Thomas, and Percy and Laurie,

22. Jim and Trevor, Wally and Max,

23. Chris, Dave and Warren.

24. But again, the shadows danced. Now there were only the scrubby lands to the west and the dry lands north of the Goyder Line to be had, and so the men must abide the times of drought and flood, the times of fire and wind, the times of pestilence and complaint.

25. The king sent his tax collectors to knock on the doors of rich men, and wonders came to pass. New roads and new schools and new hospitals were built. New peoples from the old lands came to the towns and cities, there to join the returned peoples. Together all the brethren multiplied, making the king and his men happy.

26. Yet, still the shadows played and even when the king sayeth that all men must listen to the wise men in the land's mighty parliaments and law courts, and above all else to their God, the people became afflicted with burdens. The king sayeth, 'Let us deal wisely with them, lest they multiply.' And so, the shame spread across the land, hiding mothers from their babies, and babies from their mothers.

27. Now these were the names of the girls who came into the cities and convents and homes and hospitals; everyone of them on their own with only the comfort of strangers to watch their tears falling on cheeks still plump with adolescence, unlined by knowingness too great.

28. Rhonda, Janet, Mary and Brenda,

29. Dianne, Sylvia and Anne,

30. Carol, and Noelene, Grace and Astrid.

31. And all the girls and the women were many who came to these places of shame and secrets. Some say thousands and thousands, for the churches and the state were cosy together and morality was preached across the land, in the homes and the schools, the parliaments and the courts.

32. One girl, unable to give her child up into the homes of others, hid him in her mother's house. When she could no longer hide him, she got warm swaddling for him and placed the child in it and put him among the steps of the lawmaker's house.

33. Then the daughter of the lawmaker who herself had not babies around her, saw the swaddling and bent on her knees to see what was wrapped about. She opened it and saw the baby. He was crying, and she felt sorry for him. 'This is 
one of the unwanted babies,' she said. And God spake to the woman, 'Whosoever shall receive one such little child in my name, receiveth me.'

34. And God did receiveth her, as he did the many women who had themselves not born the fruit of their loins, but taketh babies in swaddling from another's loins, and lay them in their own houses as if the babies were of their making.

35. And to these babies God sayeth, 'When your father and your mother forsake you, then I took you up.'

36. All the brethren kept the secrets, and when the shadows fell across the eyes of the babies forsaken by their mothers and their fathers, grown now into sturdy men and women of the fields and cities, they quietened and did not speak, and allowed those who had been forsaken to bear silent witness.

\section{Reflecting on the creative writing}

Beginning with Australia's war efforts, I recalled the struggles and sacrifices made by women and men and children in World War I, or the Great War, as it was known. At the time, the arrival of unwanted or unexpected children into the world was largely dealt with in-family. My grandmother, for example, raised her brother's illegitimate child as her own, as did many women of her era. Formal adoption processes came into being between 1926 and 1930, when all states and territories passed laws to regulate adoption.

My father referred to a farm neighbouring our farm as Goyder's, in fact the original farmer's name even though the property had changed hands before I was born. Goyder is a name shared with the South Australian surveyor, George Goyder, who in 1865 mapped a line that separated arable land from that only capable of growing saltbush. Farms established north of this line did not flourish. Despite most Victorian farms being below the Goyder Line, the Victorian Government wanted to improve farming practice so as to increase yields and therefore achieve an improved return from agricultural exports. The 'Better Farming Train' rumbled into mind. What an idea that was. A train loaded with animals, grain, farm machinery and kitchens, staffed by agricultural scientists, infant welfare nurses and home economists, arrived throughout country Victoria in the hope of improving the practices of farmers and their wives. My grandfather who had settled his farm at Apsley before World War I told me about this train one afternoon when I sat with him after school had finished for the day. He was too weak to get out of bed, in the last stages of an illness that eventually saw him off, but not too weak to regale me with stories. I never knew if his stories were true or not, some so fantastical they must have been made up, such as the story he told about putting a snake in a tomato sauce bottle, scaring the living daylights out of the next man to upend the bottle. My grandfather hadn't seen the train himself, as travelling forty-odd miles in a horse-drawn vehicle and back again was not possible for a man with cows to milk, chooks and dogs to feed, and sheep to tend. But he knew people who had seen it arrive and set up in Kaniva. Years later, I read Carrie Tiffany's Everyman's Rules for Scientific Living (2005), itself an ironic tale about the inability of science to counteract poor land and farming, miring the protagonist and her idealist husband into spiralling despair, and the train sprang to life once more.

Australian soldiers who were returning from war fronts were essentially exiled by taking up offers to join the Soldier Settlement Scheme where on often near-barren land they were expected to raise families and contribute to Australia's economy (Returning soldiers 2018). Sandwiched between the two world wars, Australia suffered a crippling economic depression. My mother and aunts told me about the 
swaggies who offered to chop wood in return for food, men who were 'on the wallaby' as brutally described in Frank Huelin's book Keep Moving (1973).

After World War II, returned servicemen were again given land by governments, but not near enough land to make much of a living from farming. Their kids grew up on soldier settlement blocks at Langkoop. Tired, hard land. No one made a fortune out there until wool prices soared and the lucky few who ran enough sheep could cash in. Snatches and breaths of memory struggled for recognition. Further afield, migrants from war-ravaged Europe set up homes in the inner suburbs of Melbourne. On trips to visit my aunt in Fitzroy in the 1950s I overheard strange languages from next door's back yard and on the Number 96 tram when families crammed aboard on their way to St Kilda for a day at the beach.

\section{Reflecting on the Bible's influence in the creative work}

Within the King James version of the Bible's First Testament, the prose/poetry adopts a narrative style. The translators, who crafted the version from the original Hebrew and Aramaic, scripted only the events. Like students in a modern creative writing class, it is as if these men had been instructed to abandon the adjective, use active verbs, keep the subject close to its object, unlike Phillip Lopate who advises essayists to write like James Baldwin: 'Baldwin's sheer love of language; his intoxication with adjectives and adverbs, at a time when other writers were starting to avoid them' (2013: 183).

Northrop Frye argues that biblical narrative is reminiscent of folktales: a hero sets out on a quest and succeeds, as described in language that is 'primarily poetic' (Lopate 2013: 183). In my creative work, the 'hero' is the amalgam of the church and the state seeking to resolve the social issues - that of babies born out of wedlock - by imposing political remedies; the language choices I made in the naming of the men and the women, using symbols to mark the passage of time, and repetition to build the narrative, are a copy of the structure and metre of the Exodus chapters.

Words can be any number of things: plain or fancy, utilitarian or exotic, deliciously evocative or dully familiar. David Morley argues that,

Language is made to live through poems, but the living language of poetry does not simply begin and end with the meaning of your words...words are sticky with meaning, history and association ... brought to life through their choice and combination - and by chance, especially the chances created by metre, rhyme and form ... Poetry's precision of expression, its accent on the sounds of language, draws the writer taken by the clatter and tilt of words. (1982: 139)

Like many things, some of these 'clattering and tilting' words have gone out of fashion, and are rarely, if ever, used by contemporary writers. Because of this we have lost the meaning for 'loin', unless we are purchasing lamb chops, just as we have lost 'verily', infinitely preferable, in my view, to today's commonplace phrase, 'to tell you the truth'. How many of our lives are now 'bitter with hard bondage'? Instead we say we are 'so busy' and 'just stressed-out', complaining that we 'lack work-life balance', replete with the many convoluted meanings such a phrase infers. Women being described as 'lively' when giving birth expresses the quick terror and joy of it all so much better than the term 'a fast labour'. And who wears a 'pinafore' now, or as my Granny used to call them, 'pinnies'? She made them for me out of doublebacked hessian, so I could stay dry when feeding pet lambs. Invariably, one lamb would somehow manage to tug the teat off its bottle, resulting in warm milk squirting everywhere, including over me. I felt it was important to use the language of the eras 
about which I was writing, the early 1900s and the 1950s, even if it did mean selecting words no longer in common use.

Robert Alter refers to 'symmetry and repetition' (2007: 200-201), aspects of literary parallelism, as key elements in biblical poetic narrative, quoting T.H. Robinson in support: 'the poet goes back to the beginning again, and says the same thing once more, though he [sic] may partly change the words to avoid monotony' (1981: 5). Alter claims that 'literature thrives on parallelism, both stylistic and structural ... and could not give its creation satisfying shape without it' (1981, p. 9). Repetition is central to the two chapters in Exodus that I re-constructed in my hermit crab essay, and as a rhetorical device, it aims to structure the reader's attention and anchor interpretation (1981: 10). David Morley states that 'in the same way that paragraphs of prose have the effect of herding words into a point' (Mazur 2005), repetition in poetry 'plants avenues of words to help drive a poem forward' (2007: 196). Read out loud Exodus Chapter 1 verses 2 to 4 . Listen to the lilting of the syllables, the cadence almost the same, but not quite, like water trickling through a stream encountering a fallen twig. For me, this was hypnotising and I wanted to replicate it, and in so doing, replicate the hypnotising effects of the policies of shame and silence.

\section{Conclusion}

Beginning in the 1920s, for more than 60 years, Australian children were removed from their mothers, details of their parentage and identity were legally altered, and the mothers were prevented from knowing who their children had become. However, because the Christian church in Australia was an influential player in forming Australian public policy regarding infant adoption, it is my aim in this creative work to emphasise the connection between church and state by using the primary Christian text, the Bible. Just as Moses was taken from the bulrushes, which transformed him from a Hebrew to an Egyptian prince, Australian children were taken from their biological and cultural bases and transformed into other people's children. Baker claims that 'a writer who turns to a Biblical episode for any metaphorical or illustrative purpose ought to be content to treat it allusively, to allow it to operate in the realm of suggestion' (2007: 197). The Bible offers rich narrative, noteworthy characters and a poetic treasure-trove, making it a highly relevant text in my creative work.

\section{Works cited}

ABC 2012, 'Archbishop apology for forced adoptions welcome', ABC News (1 September): http://www.abc.net.au/news/2012-09-01/anglican-church-apology-for-force-adoptionswelcomed/4237760 (accessed 10 September 2018)

Alter, R 1981 The Art of Biblical Poetry, Basic Books, New York

Army, TS 2012 'The Salvation Army Apologises to People Affected by Forced Adoptions', The Salvation Army (19 September): https://salvos.org.au/about-us/latest-news/medianewsroom/20120919-tsaue-apologises-forced-adoptions/ (accessed 3 July 2017)

Baker, C 1960 'The Place of the Bible in American Fiction', Theology Today 17: 53-76

Cole, C 2013, 'Stolen Babies - Broken Hearts: Forced Adoption in Australia, 1881-1987' (June) PhD thesis, the University of Western Sydney

de Certeau, M 1984 Practice of Everyday Life, University of California Press, Berkeley 
Department of Families and Community 2009 History and Statistics of Adoption in South Australia, Government of South Australia: http://www.dfc.sa.gov.au/pub/tabid/231/itemid/562/History-andstatistics-of-adoption-in-South-Austra.aspx (accessed 12 April 2009)

Frye, N 1982 The Great Code: the Bible and Literature, Harcourt Brace Jovanovich, New York

Gair, S 2012, 'Re-writing Australia's history of forced adoption', The Conversation (28 February): https://theconversation.com/re-writing-australias-history-of-forced-adoption-5142 (accessed 10 September 2018)

Gillard, J 2013 'National Apology For Forced Adoptions’, Australian Government: https://www.ag.gov.au/About/ForcedAdoptionsApology/Documents/Nationalapologyforforcedadoptio ns.PDF (accessed 9 May 2014)

Higgins, D 2012 Past and present adoptions in Australia, Australian Institute of Family Studies, Commonwealth of Australia: http://www.aifs.gov.au/institute/pubs/factssheets/2012/fs201202/fs201202.html-a2 (accessed 21 October 2014)

Huelin, F 1973 Keep Moving, Penguin, Ringwood

Human Rights and Equal Opportunity Commission 1997 Bringing Them Home: Report of the National Inquiry into the Separation of Aboriginal and Torres Strait Islander Children from Their Families, Commonwealth of Australia, Canberra

Kenny, P, D Higgins, C Soloff \& R Sweid 2012 Past Adoption Experiences: National Research Study on the Service Response to Past Adoption Practices, final report, Institute of Family Studies, Australia

Kincheloe, JL 2016 'Describing the Bricolage: Conceptualizing a New Rigor in Qualitative Research', Qualitative Inquiry 7, 6: 679-692

Levi-Strauss, C 1966 The Savage Mind, University of Chicago Press, Chicago

Lopate, P 2013 To Show and To Tell: the Craft of Literary Nonfiction, Free Press, New York

Mackellar, CS 1913 The Treatment of Neglected and Delinquent Children in Great Britain, Europe, and America with Recommendations as to Amendment of Administration and Law in New South Wales, Legislative Assembly, New South Wales, Sydney

Mazur, K 2005 Poetry and Repetition, Routledge \&Taylor \& Francis, New York

Miller, B \& S Paola 2012 Tell it Slant, 2nd edn, McGraw Hill, New York

Morley, D 2007 Cambridge Introduction to Creative Writing, Cambridge University Press

New South Wales Parliament 1999 Report on Adoption Practices Second Interim Report, 366, Legislative Council Standing Committee on Social Issues, New South Wales

Quartly, M, S Swain \& D Cuthbert 2013 The Market in Babies, Monash University Publishing, Clayton

Quirk, C 2012 'Separated at Birth: Adoption practices in relation to single women confined at the Royal Women's Hospital 1945-1975’ (January) MA thesis, Australian Catholic University

Read, P 1981 The Stolen Generations: the removal of Aboriginal children in New South Wales $1883-$ 1969, New South Wales Government Publications, Sydney

'Returning soldiers' 2018 State Library of Victoria: http://ergo.slv.vic.gov.au/explore-history/australiawwi/abroad-wwi/returning-soldiers (accessed 20 June 2018)

Robinson, M 2011 'The Book of Books: What Literature Owes the Bible', New York Times (22 December): https://www.nytimes.com/2011/12/25/books/review/the-book-of-books-what-literatureowes-the-bible.html (accessed 10 May 2014)

Rosenbaum, A 2012 'Church Adoption Apology', Sydney Morning Herald (28 February): https://www.smh.com.au/national/church-adoption-apology-20120227-1tyy6.html (accessed 19 June 2018) 
Rudd, K 2008, Apology to Australia's Indigenous Peoples, Australian Government: http://australia.gov.au/about-australia/our-country/our-people/apology-to-australias-indigenous-peoples (accessed 9 May 2014)

Rudd K 2009 An Apology to the Forgotten Australians and Former Child Migrants, Australian Government: http://forgottenaustralianshistory.gov.au/apology.html (accessed 9 May 2014)

Senate Community Affairs References Committee 2004 Forgotten Australians: a report on Australians who experienced institutional or out-of-home care as children, Australian Government, Canberra

Standing Committee on Social Issues 2000 Releasing the past: adoption practices, 1950-1998: final report, 600, New South Wales Parliament Legislative Council, New South Wales

Swain, S \& R Howe 1996 Single mothers and their children: disposal, punishment and survival in Australia, Studies in Australian History, Cambridge University Press, Cambridge

Tiffany, C 2005 Everyman's Rules for Scientific Living, Picador, Sydney

Wakatama, G 2011 'Church says sorry over forced adoptions', ABC News (25 July): http://www.abc.net.au/news/2011-07-25/catholic-church-apologises-over-forced-adoptions/2808672 (accessed 7 December 2015)

Walker, N \& M Singer (eds) 2013 Bending Genre: Essays on Creative Nonfiction, Bloomsbury, New York 